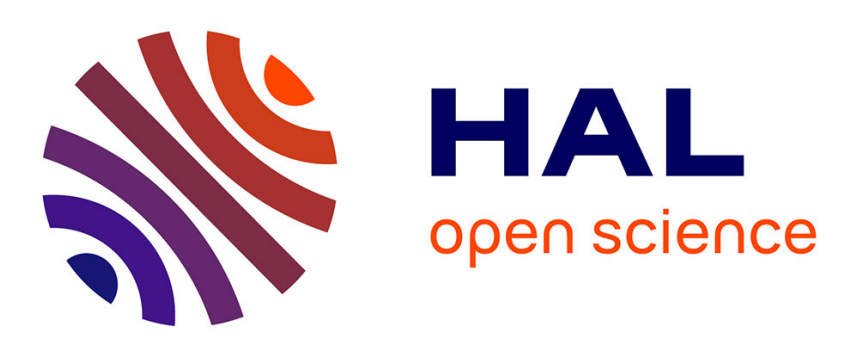

\title{
Tailoring residual stress profile of Selective Laser Melted parts by Laser Shock Peening
}

Nikola Kalentics, Eric Boillat, Patrice Peyre, Snezana Ciric-Kostic, Neboj`sa Bogojevi, Roland E. Logé

\section{- To cite this version:}

Nikola Kalentics, Eric Boillat, Patrice Peyre, Snezana Ciric-Kostic, Neboj`sa Bogojevi, et al.. Tailoring residual stress profile of Selective Laser Melted parts by Laser Shock Peening. Additive Manufacturing, 2017, 16, pp.90-97. 10.1016/j.addma.2017.05.008 . hal-01676351

\section{HAL Id: hal-01676351 \\ https://hal.science/hal-01676351}

Submitted on 5 Jan 2018

HAL is a multi-disciplinary open access archive for the deposit and dissemination of scientific research documents, whether they are published or not. The documents may come from teaching and research institutions in France or abroad, or from public or private research centers.
L'archive ouverte pluridisciplinaire HAL, est destinée au dépôt et à la diffusion de documents scientifiques de niveau recherche, publiés ou non, émanant des établissements d'enseignement et de recherche français ou étrangers, des laboratoires publics ou privés. 


\title{
Tailoring residual stress profile of Selective Laser Melted parts by Laser Shock Peening
}

\author{
Nikola Kalentics ${ }^{\mathrm{a}, *}$, Eric Boillat ${ }^{\mathrm{a}}$, Patrice Peyre ${ }^{\mathrm{b}}$, Snežana Ćirić-Kostićc ${ }^{\mathrm{c}}$, \\ Nebojša Bogojevićc ${ }^{c}$, Roland E. Logéa

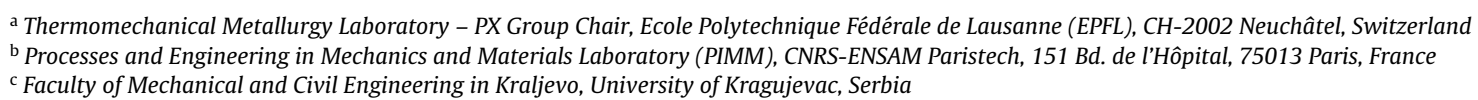

Keywords:

Selective laser melting

Laser shock peening

3D Laser shock peening

Residual stress profile

15-5 PH stainless steel

316L stainless steel

\begin{abstract}
A B S T R A C T
The paper describes a new approach in controlling and tailoring residual stress profile of parts made by Selective Laser Melting (SLM). SLM parts are well known for the high tensile stresses in the as - built state in the surface or subsurface region. These stresses have a detrimental effect on the mechanical properties and especially on the fatigue life. Laser Shock Peening (LSP) as a surface treatment method was applied on SLM parts and residual stress measurements with the hole - drilling method were performed. Two different grades of stainless steel were used: a martensitic 15-5 precipitation hardenable $\mathrm{PH} 1$ and an austenitic 316L. Different LSP parameters were used, varying laser energy, shot overlap, laser spot size and treatments with and without an ablative medium. For both materials the as-built $(A B)$ residual stress state was changed to a more beneficial compressive state. The value and the depth of the compressive stress was analyzed and showed a clear dependence on the LSP processing parameters. Application of LSP on SLM parts showed promising results, and a novel method that would combine these two processes is proposed. The use of LSP during the building phase of SLM as a "3D LSP" method would possibly give the advantage of further increasing the depth and volume of compressive residual stresses, and selectively treating key areas of the part, thereby further increasing fatigue life.
\end{abstract}

\section{Introduction}

Selective laser melting (SLM) is a part of a large family of Additive Manufacturing (AM) processes. Over the last decades more than thirty different types of Additive Manufacturing processes have been developed [1,2], with SLM being one of the most researched over the past years.

However, although the mechanical properties have become close to those of bulk materials [3-14], SLM has some inherent drawbacks such as warping, cracking and detrimental tensile residual stresses (TRS). A large degree of shrinkage occurs during liquid - solid transformation, thus accumulating considerable tensile residual stresses on the surface of the SLM produced components. The complex residual stresses (RS) that arise during cooling are regarded as key factors responsible for the distortion and even delamination of the final parts [9,10,15-17]. These residual stresses may even cause process failure during the building phase [18].

\footnotetext{
* Corresponding author.

E-mail address: nikola.kalentics@epfl.ch (N. Kalentics).
}

The last melted layer shrinks during cooling while the layer underneath, already solidified constrains it and prevents further shrinking $[15,16]$. Since this mechanism occurs for each layer at each step of the SLM process, large tensile residual stresses accumulate inside the manufactured component which cause significant and detrimental anisotropy of the mechanical properties of produced parts $[5,7,19-21]$ thus limiting their application.

Different methods have arisen to reduce residual stresses. In situ heating (e.g. build plate heating; reheating of the melt pool) is commonly used [15,22]. Adapting scanning strategies can also have a strong impact on residual stresses [15,23]. As a post treatment, annealing is widely used and has demonstrated in some cases a 70 percent reduction of residual stresses [24]. Although these methods have demonstrated certain improvements of the final residual stress state, they have shown to be unable to completely remove tensile residual stresses. In the case of annealing, as a post treatment it is limited to addressing this issue only after the building process is done, and as such it cannot address the issue of stress accumulation that can cause process failure.

In the present paper, a novel strategy is proposed for tailoring residual stresses in parts manufactured by SLM by using another 
laser treatment - Laser Shock Peening. The goal of this approach is to fully transform the residual stress state from a detrimental tensile to a beneficial compressive residual stress (CRS) in the near surface region. Additional benefit of the proposed approach is that it might be introduced as an in situ treatment during the SLM process.

Laser Shock Peening (LSP) is a high strain rate (on the order of $10^{6} \mathrm{~s}^{-1}$ ) [25], surface treatment process, that is similarly to Shot Peening (SP) and Ultrasonic Shot Peening (USP) used to introduce compressive residual stresses and plastic deformation into the surface of the material. The compressive stress can reach a depth of several millimeters and may counteract some or all of the tensile stress, decrease the crack propagation rate, effectively reduce the stress intensity factors, enhance the fatigue crack closure effect and increase the critical stress of crack propagation, thus improving the fatigue performance of metal materials (Fig. 1) [26-29]. This positive effect of LSP was shown on many different materials such as aluminum alloys $[25,26,30,31]$ titanium alloys $[28,32,33]$ nickel based alloys [34-36], stainless steel [29] etc.

It has been shown that the residual stresses can be directly related to the fatigue life of samples [25,27-29,31-33,37,38] with a clear beneficial effect of compressive stresses in the near surface region. It was also observed that the depth of the compressive residual stresses has a direct influence on the fatigue life. The larger the depth, the longer CRS will interact with the surface crack, resulting in a slower crack propagation and a longer fatigue life. Compared to other similar processes such as Shot Peening (SP) or Ultrasonic Shot Peening (USP), LSP treatment introduces CRS to a larger depth, thus leading to an increase in fatigue life of LSP samples compared to SP and USP samples [27,32,39,30,40-42]. The proposed strategy of combining SLM with LSP has a goal of further increasing the depth and amount of CRS in the near surface region.

\section{Experimental setup}

\subsection{Material}

Materials used in this paper are two grades of stainless steel, PH1 and 316L. PH1 with a standard denomination 15-5 PH, is a martensitic precipitation hardenable stainless steel made by the SLM machine producer EOS (EOS GmbH, Germany). PH1 has an ultimate tensile strength (UTS) of $1150 \mathrm{MPa}$ [43] and provides excellent mechanical properties, especially in the precipitation hardened state. It is widely used in medical, aerospace and other engineering applications requiring high hardness and strength. PH1 samples were produced on an EOSINT M280 additive manufacturing machine, with a closed set of parameters and a fixed scanning strategy provided by the machine producer for this powder.

$316 \mathrm{~L}$ is a widely used austenitic stainless steel and has an UTS of $760 \mathrm{MPa}$ [44]. The powder that was used was DIAMALLOY 1003 obtained from Sulzer Metco, Switzerland. These samples were produced on a Concept laser M2 (Concept Laser GmbH, Germany) machine equipped with a fiber laser operated in continuous mode at a wavelength of $1070 \mathrm{~nm}$ and a spot size of $90 \mu \mathrm{m}$. The parameters laser power, scanning speed, hatch distance and powder layer thickness were $125 \mathrm{~W}, 600 \mathrm{~mm} / \mathrm{s}, 0.105 \mathrm{~mm}$ and $0.03 \mathrm{~mm}$, respectively. A bi-directional scanning strategy that was parallel to the part edges was used in every layer without a change in scanning direction between layers. This was done to deliberately create large tensile residual stresses and to show the ability of the LSP process to address even such stresses and to convert them to CRS.

The chemical composition of both PH1 and 316L stainless steel is shown in Table 1.

\subsection{Laser shock peening}

Laser shock peening (LSP) experiments were made at the PIMM laboratory at CNRS-ENSAM Paristech [45]. The laser source used is a $7.1 \mathrm{~ns}$ at $532 \mathrm{~nm} \mathrm{Nd:YAG} \mathrm{GAIA} \mathrm{-} \mathrm{class} \mathrm{laser} \mathrm{from} \mathrm{Thales} \mathrm{Laser}$ company. The beam spatial energy distribution is "top-hat" and the pulse shape is near - Gaussian. LSP processing parameters are shown in Table 2. Round laser spots of 1,2 and $5 \mathrm{~mm}$ diameter were used with the laser energy of $0.4,1.6$ and $10 \mathrm{~J}$ respectively. This ratio of the spot size and the energy kept the power density constant at $7.2 \mathrm{GW} / \mathrm{cm}^{2}$. The pressure at the surface of the treated part was estimated at $4.7 \mathrm{GPa}$ using an empirical equation $P(G P a)=1.75 \sqrt{I_{0}}\left(\frac{G W}{\mathrm{~cm}^{2}}\right)$ [46]. Pulse frequency was $1 \mathrm{~Hz}$, and the overlap of $40 \%$ was used for all spot sizes with and without a protective ablative coating. Also one sample with an overlap of $80 \%$ was treated with a $1 \mathrm{~mm}$ spot size without an ablative coating. In order to avoid ablation of the surface of the samples, in some cases an ablative layer was used. For this purpose a sacrificial aluminum tape of $70 \mu \mathrm{m}$ thickness from $3 \mathrm{M}^{\mathrm{TM}}$ was placed on top of the sample. In other cases, the ablative layer was not applied, and the results in these two conditions were compared.

\subsection{Residual stress determination using the hole drilling method}

Residual stresses have been measured with the hole drilling method (HDM) according to the ASTM standard E837 [16,47]. It is a widely used technique for the determination of in depth residual stress profiles in parts especially after surface treatments such as LSP, USP, SP etc [47-52]. The measuring device is the RESTANMTS 3000 from SINT Technology (Fig. 2a). A 1,8 mm diameter hole is drilled into the piece to be analyzed. Residual stresses relax at the hole location causing strains also to change. A strain gage rosette with three grids measures these strains (Fig. 2b). Residual stresses are given by the theory of Kirsch [53], adjusted with experimental coefficients for blind hole analysis. Residual stresses were measured at a total of 36 points from the surface up to $1 \mathrm{~mm}$ in depth. Since the goal was to achieve more precise results of residual stresses in the near surface region, a variable depth increment was applied. In the region from the surface up to the depth of $100 \mu \mathrm{m}$, measurements were made every $10 \mu \mathrm{m}$. From $0.1 \mathrm{~mm}$ up to $0.5 \mathrm{~mm}$ in depth, measurements were made every $25 \mu \mathrm{m}$, and from $0.5 \mathrm{~mm}$ up to $1 \mathrm{~mm}$ every $50 \mu \mathrm{m}$.

\section{Results and discussion}

\subsection{PH1 stainless steel}

Fig. 3 shows some of the most important parameters of a residual stress curve. These are the maximum amount of CRS - Max CRS, depth at which maximum CRS are observed - Depth of max CRS, depth at which change from CRS to TRS - Depth of CRS, and the value of CRS in the near surface region, at the depth of $20 \mu \mathrm{m}-$ Surface RS.

Residual stress measurements of the PH1 samples made by SLM in the as - built (AB) state show a low amount of compressive residual stresses (CRS) in the near surface region up to the depth of $183 \mu \mathrm{m}$ (Fig. 4). Compressive residual stress in this near surface region of SLM samples is a rare observation. However, it was also observed that welded joints of martensitic stainless steels have such compressive residual stress state in the near surface zone [54-56]. The reason for their occurrence is that martensitic stainless steels experience a phase transformation during the cooling period. During this phase change, the crystal lattice expands and the accumulated stresses due to the shrinkage are relaxed and inversed 


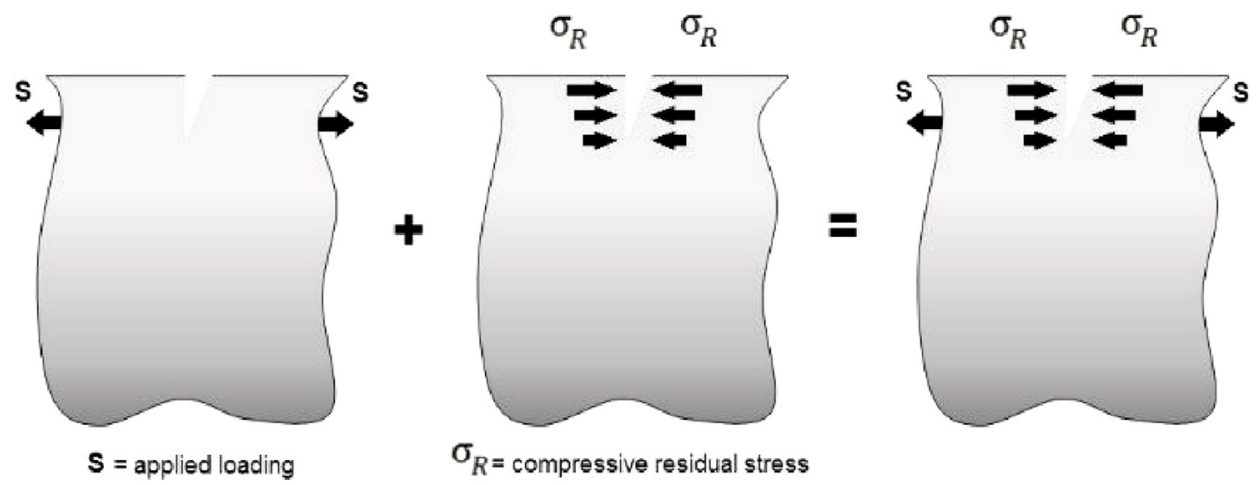

Fig. 1. Effect of tensile and compressive stresses on the crack growth propagation.

Table 1

Chemical composition of PH1 and 316L stainless steel, wt.\% [43].

\begin{tabular}{|c|c|c|c|c|c|c|c|c|c|}
\hline & $\mathrm{Cr}$ & $\mathrm{Ni}$ & $\mathrm{Cu}$ & Mn & $\mathrm{Si}$ & Mo & $\mathrm{Nb}$ & $\mathrm{C}$ & $\mathrm{Fe}$ \\
\hline PH1 & $14-15.5$ & $3.5-5.5$ & $2.5-4.5$ & $\max 1$ & $\max 1$ & $\max 0.5$ & $0.15-0.45$ & $\max .0 .07$ & Balance \\
\hline $316 \mathrm{~L}$ & 17 & 12 & 1 & 1 & 2.3 & 2.5 & 1 & 0.03 & Balance \\
\hline
\end{tabular}

Table 2

LSP processing parameters: spot size; E - laser energy; $I_{0}$ - power density; P - estimated pressure at the surface; frequency.

\begin{tabular}{|c|c|c|c|c|}
\hline Spot size $(\mathrm{mm})$ & $E(J)$ & $I_{0}\left(\mathrm{GW} / \mathrm{cm}^{2}\right)$ & $\mathrm{P}(\mathrm{GPa})$ & Frequency $(\mathrm{Hz})$ \\
\hline 1 & 0.4 & 7.2 & 4.7 & 1 \\
\hline 2 & 1.6 & 7.2 & 4.7 & 1 \\
\hline 5 & 10 & 7.2 & 4.7 & 1 \\
\hline
\end{tabular}

a

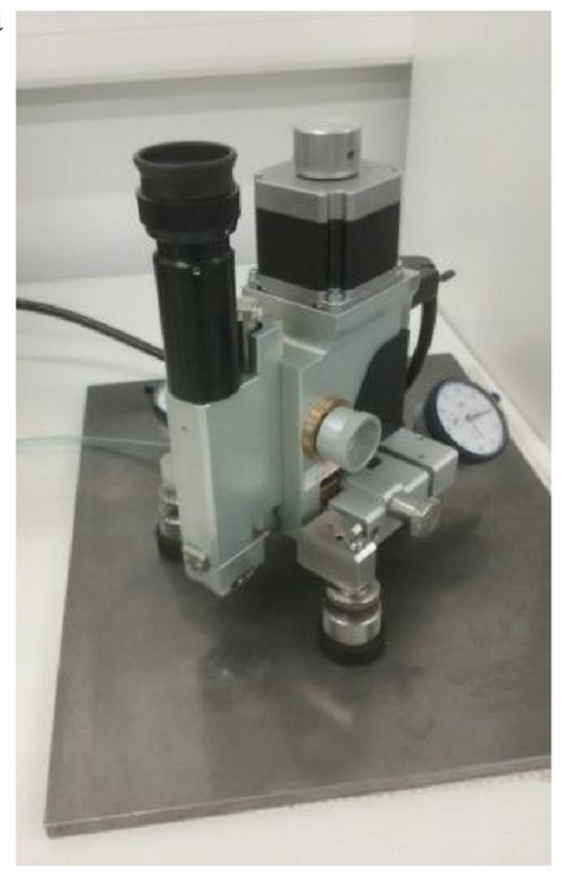

b

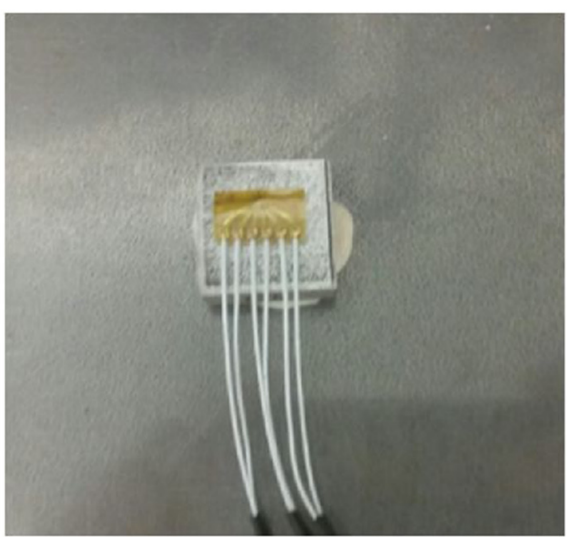

Fig. 2. a) Hole drilling device RESTAN-MTS 3000 from SINT Technology, b) sample with attached strain gage rosette for HDM.

to a small negative value (i.e. to a compressive residual stress value) [44].

The maximum amount of the observed CRS is $-230 \mathrm{MPa}$ at the depth of $94 \mu \mathrm{m}$ which presents a $20 \%$ of its UTS of the material which is $1150 \mathrm{MPa}$. The value of the surface RS is $-41 \mathrm{MPa}$ ( $4 \%$ of the UTS). Beyond $183 \mu \mathrm{m}$, the residual stress state changes towards tensile state. Above the depth of $183 \mu \mathrm{m}$ where the stresses are neutral, we can observe a sudden increase in TRS up to the depth of around $340 \mu \mathrm{m}$ where the TRS have a value of $435 \mathrm{MPa}$ (38\% of the UTS). Beyond this point we can see a slower increase in the amount of tensile stresses throughout the whole depth of the measurement.

Other samples made by SLM were treated with Laser shock peening. Table 3 . gives an overview of results of residual stress measurements done on samples in the as - built and LSP treated state and a graphical representation is given in Fig. 4. 


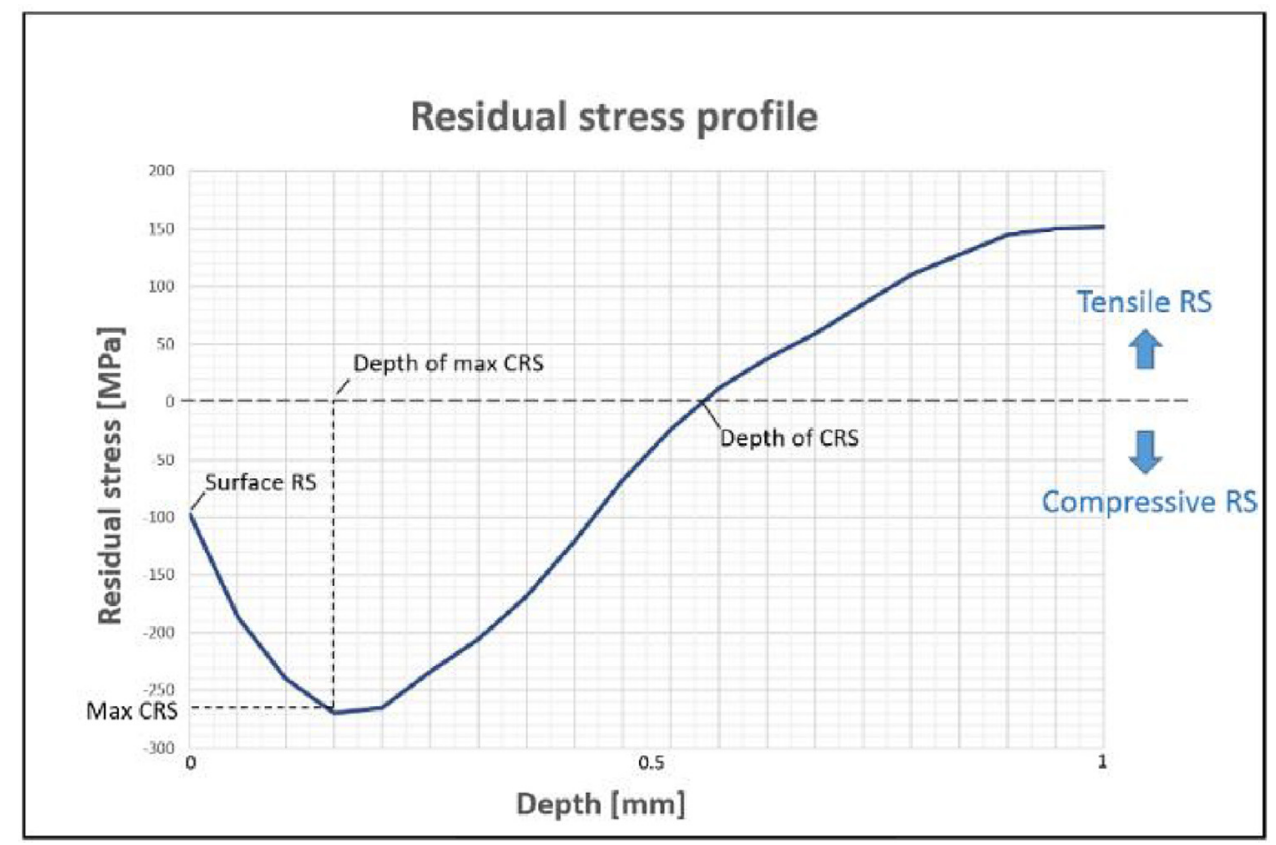

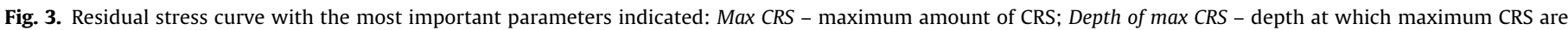
observed; Depth of CRS - depth at which residual stresses change from CRS to TRS; Surface RS - value of CRS in the near surface region, at the depth of $20 \mu \mathrm{m}$.
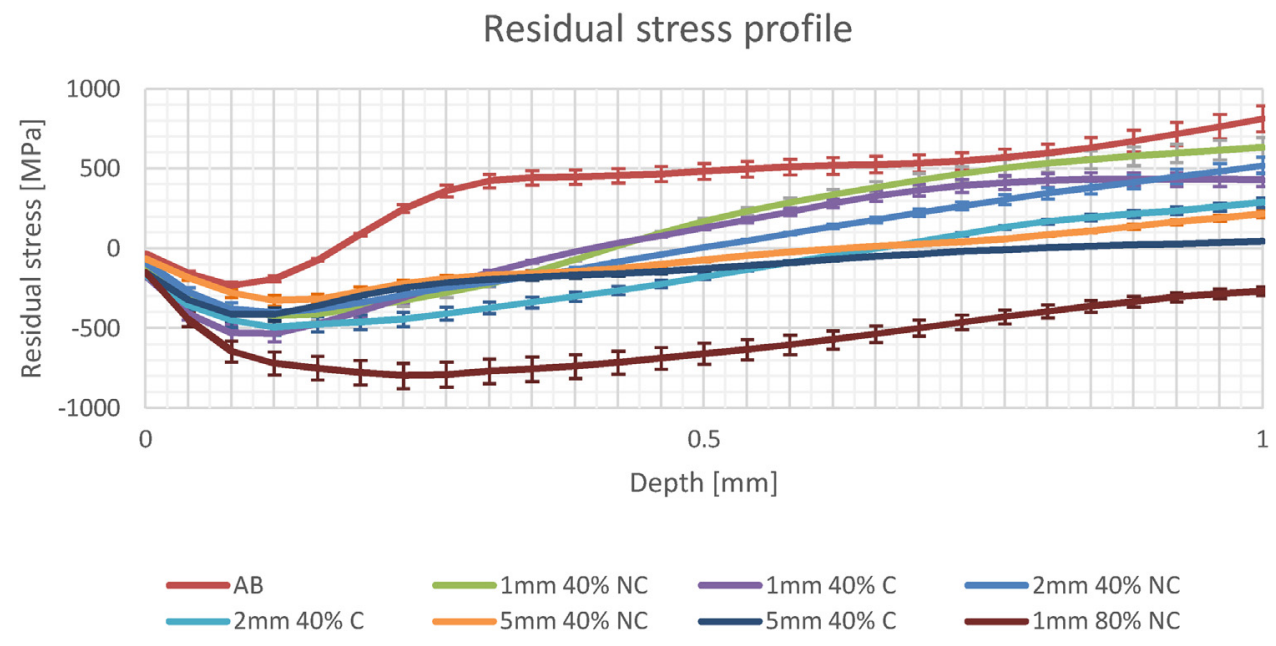

Fig. 4. Residual stress curves measured for samples in the as - built and different LSP treated states.

Table 3

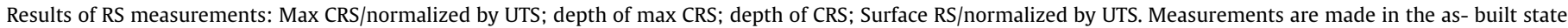
$(\mathrm{AB})$, or with LSP treatments of 1,2 and $5 \mathrm{~mm}, 40$ and $80 \%$ overlap, and with and without an ablative coating (C/NC).

\begin{tabular}{|c|c|c|c|c|}
\hline LSP treatment & $\begin{array}{l}\text { Max CRS } \\
\text { [MPa]/percentage } \\
\text { of the UTS [\%] }\end{array}$ & $\begin{array}{l}\text { Depth of max } \\
\text { CRS }[\mu \mathrm{m}]\end{array}$ & $\begin{array}{l}\text { Depth of CRS } \\
{[\mu \mathrm{m}]}\end{array}$ & $\begin{array}{l}\text { Surface RS } \\
\text { [MPa]/percentage } \\
\text { of the UTS [\%] }\end{array}$ \\
\hline $1 \mathrm{~mm} \mathrm{40 \%} \mathrm{NC}$ & $-421 / 37$ & 142 & 406 & $-117 / 10$ \\
\hline $1 \mathrm{~mm} \mathrm{40 \%} \mathrm{C}$ & $-530 / 46$ & 115 & 403 & $-187 / 16$ \\
\hline $2 \mathrm{~mm} 40 \% \mathrm{NC}$ & $-401 / 35$ & 136 & 495 & $-103 / 9$ \\
\hline $2 \mathrm{~mm} \mathrm{40 \%} \mathrm{C}$ & $-494 / 43$ & 120 & 647 & $-165 / 14$ \\
\hline $5 \mathrm{~mm} \mathrm{40 \%} \mathrm{NC}$ & $-325 / 28$ & 139 & 620 & $-69 / 6$ \\
\hline $5 \mathrm{~mm} \mathrm{40 \%} \mathrm{C}$ & $-412 / 36$ & 113 & 788 & $-163 / 14$ \\
\hline $1 \mathrm{~mm} 80 \% \mathrm{NC}$ & $-798 / 69$ & 247 & $>1 \mathrm{~mm}(-266 \mathrm{MPa}$ at $1 \mathrm{~mm})$ & $-169 / 15$ \\
\hline $\mathrm{AB}$ state & $-230 / 20$ & 94 & 184 & $-42 / 4$ \\
\hline
\end{tabular}

\subsubsection{Maximum value of CRS}

3.1.1.1. LSP treatment without an ablative coating. For an LSP treatment without an ablative coating (Fig. 5), maximum CRS are $-421 \mathrm{MPa}$ for $1 \mathrm{~mm}$ spot size (37\% of the UTS), $-401 \mathrm{MPa}$ (35\%) for $2 \mathrm{~mm}$ and $-325 \mathrm{MPa}(28 \%)$ for $5 \mathrm{~mm}$, and they are observed at similar depths $(136-142 \mu \mathrm{m})$. These values make a significant improvement of $17 \%, 15 \%$ and $8 \%$ of the UTS respectively, compared to the as - built state which has CRS of $-230 \mathrm{MPa}(20 \%)$ at a depth 


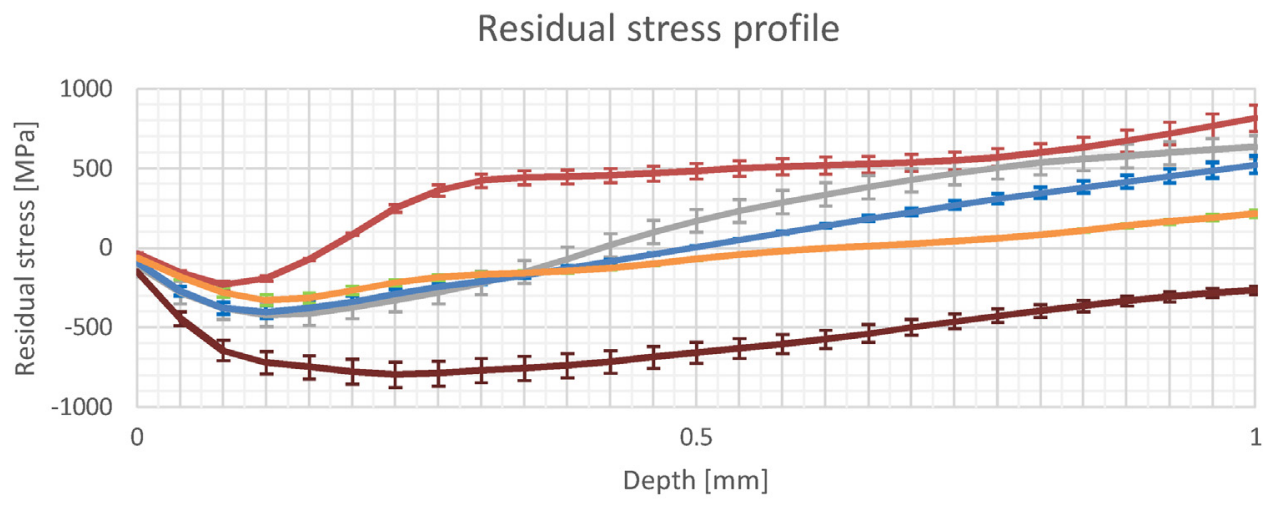

$-\mathrm{AB}=1 \mathrm{~mm} 40 \% \mathrm{NC}=2 \mathrm{~mm} \mathrm{40 \%} \mathrm{NC}=5 \mathrm{~mm} \mathrm{40 \%} \mathrm{NC}=1 \mathrm{~mm} 80 \% \mathrm{NC}$

Fig. 5. Residual stress curves measured for samples in the AB and LSP treated states without an ablative coating.

Table 4

Percentage of increase of maximum and surface CRS compared to the as built state and normalized by UTS.

\begin{tabular}{lll}
\hline LSP treatment & $\begin{array}{l}\text { Max CRS compared to the } \\
\text { AB state, and normalized } \\
\text { by UTS; [\%] of UTS }\end{array}$ & $\begin{array}{l}\text { Surface RS compared to } \\
\text { the AB state, and } \\
\text { normalized by UTS; [\%] of } \\
\text { UTS }\end{array}$ \\
\hline $1 \mathrm{~mm} \mathrm{40 \%} \mathrm{NC}$ & 17 & 6 \\
$1 \mathrm{~mm} \mathrm{40 \%} \mathrm{C}$ & 26 & 12 \\
$2 \mathrm{~mm} \mathrm{40 \%} \mathrm{NC}$ & 15 & 5 \\
$2 \mathrm{~mm} \mathrm{40 \%} \mathrm{C}$ & 23 & 11 \\
$5 \mathrm{~mm} \mathrm{40 \%} \mathrm{NC}$ & 8 & 2 \\
$5 \mathrm{~mm} \mathrm{40 \%} \mathrm{C}$ & 16 & 10 \\
$1 \mathrm{~mm} 80 \% \mathrm{NC}$ & 49 & 11 \\
\hline
\end{tabular}

of $94 \mu \mathrm{m}$. It can be observed that smaller spot size leads to larger maximum values of residual stresses. This effect was observed in literature [57] and it is presumed that since LSP with smaller spots is more often applied for a same surface area compared to LSP with larger spots, the effect is more pronounced. It is somehow equivalent to a higher number of shots, which is discussed in section 3.1.4.

3.1.1.2. LSP treatment with an ablative coating. Similar trends are observed in treatments with an ablative coating: $-530 \mathrm{MPa}$ for $1 \mathrm{~mm}$ (46\% of the UTS), $-494 \mathrm{MPa}(43 \%)$ for $2 \mathrm{~mm}$ and $-412 \mathrm{MPa}$ (36\%) for $5 \mathrm{~mm}$. In this case, this maximum values are higher compared to the treatment without the ablative coating and they are observed closer to the surface (113-120 $\mu \mathrm{m})$. These values present an even larger improvement compared to the as - built state of $26 \%$, $23 \%$ and $16 \%$ of the UTS respectively which is shown in Table 4 . Also an increase in CRS for LSP treatments with an ablative coating compared to those without an ablative coating can be observed. This is explained by the protective role of the ablative coating, since the plasma is created on its surface and not on the surface of the SLM sample. This prevents ablation and local melting of the sample surface and creation of TRS due to this melting. When the ablative coating is not applied, these TRS are decreasing the overall effect of the LSP process in both the max value of CRS and their depth.

\subsubsection{Depth of CRS}

3.1.2.1. LSP treatment without an ablative coating. If we look at the values of the depth of CRS, it can be observed that larger spot sizes lead to larger depths of CRS. For an LSP treatment without an ablative coating (Fig. 5), compressive residual stresses are observed up to depths of $406 \mu \mathrm{m}, 495 \mu \mathrm{m}$ and $620 \mu \mathrm{m}$ for laser spots of $1 \mathrm{~mm}$, $2 \mathrm{~mm}$ and $5 \mathrm{~mm}$ respectively. This presents an increase compared to the as - built state of $121 \%, 169 \%$ and $278 \%$. It can be observed that a smaller spot size leads to a smaller affected depth. This is due to the 2D attenuation of shock waves which occurs for smaller spot sizes, and that leads to decreased affected depth of the LSP treatment $[27,42,58]$.

3.1.2.2. LSP treatment with an ablative coating. For samples treated with LSP treatment with an ablative coating (Fig. 6), compressive residual stresses are observed up to the depth of or $403 \mu \mathrm{m}, 647 \mu \mathrm{m}$ and $788 \mu \mathrm{m}$ for laser spots of $1 \mathrm{~mm}, 2 \mathrm{~mm}$ and $5 \mathrm{~mm}$ respectively. This presents an increase compared to the as - built state of $119 \%$, $252 \%$ and $329 \%$. Similarly to the LSP treatment without an ablative coating, smaller spot size leads to smaller affected depths due to the $2 \mathrm{D}$ attenuation of shock waves $[27,42,58]$. Here, it can also be observed that the ablative coating due to its protective role, prevents local melting on the sample surface and thus enhances the overall effect of the LSP process. This has also an effect of further increasing the depth of compressive stresses. In the case of a $2 \mathrm{~mm}$ spot size an increase from $495 \mu \mathrm{m}$ to $647 \mu \mathrm{m}$ was observed and for the $5 \mathrm{~mm}$ spot size an increase from $620 \mathrm{~mm}$ up to $788 \mu \mathrm{m}$. Compared to the $A B$ state, this is an improvement from $169 \%$ to $252 \%$ for $2 \mathrm{~mm}$, and $278 \%$ to $329 \%$ for a $5 \mathrm{~mm}$ spot size.

\subsubsection{Surface residual stresses}

If we look at the values of the surface RS, it can be observed that the smaller spot sizes lead to larger CRS. The same tendency was observed in sections 3.1.1 and 3.1.2 in the case of the maximum amount and the depth of CRS. For samples treated without an ablative coating residual stresses are $-117 \mathrm{MPa}(10 \%)$ for $1 \mathrm{~mm}$ spot size, $-103 \mathrm{MPa}(9 \%)$ for $2 \mathrm{~mm}$ and $-69 \mathrm{MPa}(6 \%)$ for $5 \mathrm{~mm}$. This makes an increase of $6 \%, 5 \%$ and $2 \%$ of the UTS respectively, compared to the as - built state which has CRS of $-42 \mathrm{MPa}(4 \%)$.

For samples treated with an ablative coating, measured surface RS are $-187(16 \%),-165(14 \%)$ and $-163 \mathrm{MPa}(14 \%)$ for 1,2 and $5 \mathrm{~mm}$ spot size respectively. This presents an increase compared to the $A B$ state of $12 \%, 11 \%$ and $10 \%$ of the UTS. In the case of all 3 spot sizes, we can again see a significant influence of the ablative coating on the amount of CRS in the near surface region. For a $1 \mathrm{~mm}$ spot size we can observe an increase from $-117 \mathrm{MPa}(10 \%)$ to $-187 \mathrm{MPa}$ (16\%), for $2 \mathrm{~mm}$ from $-103 \mathrm{MPa}(9 \%)$ up to $-165 \mathrm{MPa}$ (14\%) and for the $5 \mathrm{~mm}$ from -69 MPa (6\%) up to - $163 \mathrm{MPa}(14 \%)$ in the uncoated/coated state respectively.

\subsubsection{Overlap rate}

One sample was treated with a higher overlap rate of $80 \%$ and without an ablative coating. For this sample the smallest spot size of $1 \mathrm{~mm}$ was used, as this value might be preferential for the LSP treatment of small and complicated parts made by SLM. These 


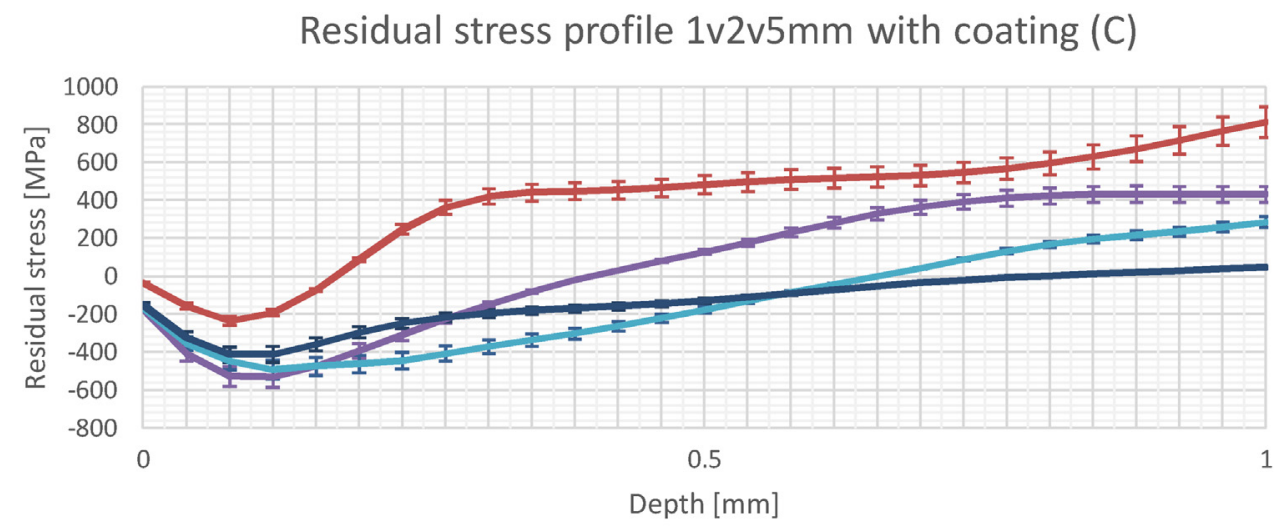

$\longrightarrow \mathrm{AB}=2 \mathrm{~mm} 40 \% \mathrm{C} 40 \% \mathrm{C} \quad-5 \mathrm{~mm} 40 \% \mathrm{C}$

Fig. 6. Residual stress curves measured for samples in the AB and LSP treated states with protective coating.

Table 5

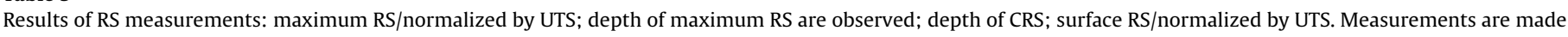
in the as- built state (AB), or with LSP treatments of $1 \mathrm{~mm}, 40$ and $80 \%$ overlap, without an ablative coating (NC).

\begin{tabular}{|c|c|c|c|c|}
\hline LSP treatment & $\begin{array}{l}\text { Max } \\
\text { RS[MPa]/percentage } \\
\text { of the UTS [\%] }\end{array}$ & $\begin{array}{l}\text { depth of max RS } \\
{[\mu \mathrm{m}]}\end{array}$ & $\begin{array}{l}\text { depth of CRS } \\
{[\mu \mathrm{m}]}\end{array}$ & $\begin{array}{l}\text { Surface RS } \\
\text { [MPa]/percentage } \\
\text { of the UTS [\%] }\end{array}$ \\
\hline $316 \mathrm{~L}-\mathrm{AB}$ & $342 / 45$ & 131 & 1 & $105 / 14$ \\
\hline $316 \mathrm{~L}-1 \mathrm{~mm} 40 \% \mathrm{NC}$ & $-266 / 35$ & 128 & 416 & $-103 / 14$ \\
\hline $316 \mathrm{~L}-1 \mathrm{~mm} 80 \% \mathrm{NC}$ & $-730 / 96$ & 94 & 804 & $-418 / 55$ \\
\hline
\end{tabular}

measurements showed a high increase in all the important features of the residual stress profile. Maximum residual stresses were $-798 \mathrm{MPa}(69 \%)$, observed at a depth of $247 \mu \mathrm{m}$, compared to $-421 \mathrm{MPa}(37 \%)$ at $142 \mu \mathrm{m}$ for $1 \mathrm{~mm} 40 \%$ overlap LSP treatment done also without a coating. These values presented the largest increase compared to the AB state with $49 \%$ increase of the UTS in the amount of CRS and a 163\% increase in depth of the maximum CRS. Surface RS were - $169 \mathrm{MPa}$ (15\%), which was an increase of $11 \%$ of the UTS compared to the AB state. Depth of the CRS, was above $1 \mathrm{~mm}$ which was the range of the measurement. At the depth of $1 \mathrm{~mm}$ they were still compressive with a value of $-266 \mathrm{MPa}(23 \%)$. With an increase by a factor of 2 in the overlap rate from $40 \%$ to $80 \%$, we have an increase by a factor of 9 of the total number of shots on the treated surface. This large increase in the total number of shots leads to a significant increase in all measured RS parameters, i.e. maximum CRS, depth of max CRS, depth of CRS and surface RS, shown in Fig. 5.

\subsection{6 stainless steel}

Since the PH1 SLM samples in the as built state showed unusual CRS in the near surface region, 316L SLM samples were used to show the potential of the LSP treatment on other materials and the ability to fully transform TRS to CRS. 316L was chosen because of its wide spread application, but also because it is an austenitic stainless steel that has a TRS state in the near surface region that is more common for SLM parts. The characteristic values in the AB and LSP treated states are shown in Table 5 and the curves of both samples made of $316 \mathrm{~L}$ and $\mathrm{PH} 1$ with same treatments in Fig. 7.

In the $A B$ state, we observed TRS in the whole range from the surface up to the $1 \mathrm{~mm}$ depth. The maximum value in the near surface region was $342 \mathrm{MPa}$ at about $131 \mu \mathrm{m}$ which represents $45 \%$ of the UTS of the material (760 MPa).

LSP treatment with a $1 \mathrm{~mm}$ spot size, no coating and $40 \%$ and $80 \%$ overlap was done. For the sample treated with a $40 \%$ overlap, CRS were observed up to the depth of $416 \mu \mathrm{m}$. The maximum value of CRS was $266 \mathrm{MPa}(35 \%)$ at $128 \mu \mathrm{m}$, and surface RS were $-103 \mathrm{MPa}(14 \%)$. For the sample treated with an $80 \%$ overlap, CRS were observed up to the depth of $804 \mu \mathrm{m}$. The maximum value of CRS was $-729 \mathrm{MPa}(96 \%)$ at $94 \mu \mathrm{m}$ and in the surface region $-418 \mathrm{MPa}(55 \%)$ at a $20 \mu \mathrm{m}$ depth. The maximum value of CRS represents $96 \%$ of the UTS of the material which indicates material strain hardening due to the high number of LSP shots on the surface in the $80 \%$ overlap LSP condition.

Tensile residual stresses are very efficiently converted to compressive residual stresses for $316 \mathrm{~L}$ samples, and the asymptotic profile is qualitatively similar to that of the PH1 samples.

\section{Conclusions}

In this paper, the capability of the LSP treatment to alter the residual stresses of SLM parts was demonstrated. It was shown that in the case of the martensitic PH1 stainless steel, the maximum amount, depth of the profile and amount in the near surface region of the beneficial CRS can be drastically increased. Also, for the austenitic 316L stainless steel, the highly tensile state of the $A B$ sample was changed to a beneficial CRS state. Various LSP processing parameters were used, with and without an ablative coating. It can be concluded that:

- Laser shock peening can be used to effectively and easily change the residual stress profile. Even with a single pass, the RS changes from tensile to compressive in the case of $316 \mathrm{~L}$, or in the case of PH1, the values of CRS are drastically increased and observed to larger depths.

- Smaller spot size leads to larger amount of residual stresses both in the near surface region and in the depth. These trends were observed both with and without an ablative coating.

- Larger spot sizes lead to increased depths of CRS.

- Ablative coating leads to larger and deeper CRS. This is true for the entire profile, in particular in the near surface region (at $20 \mu \mathrm{m}$ ) and at the maximum value of CRS. 

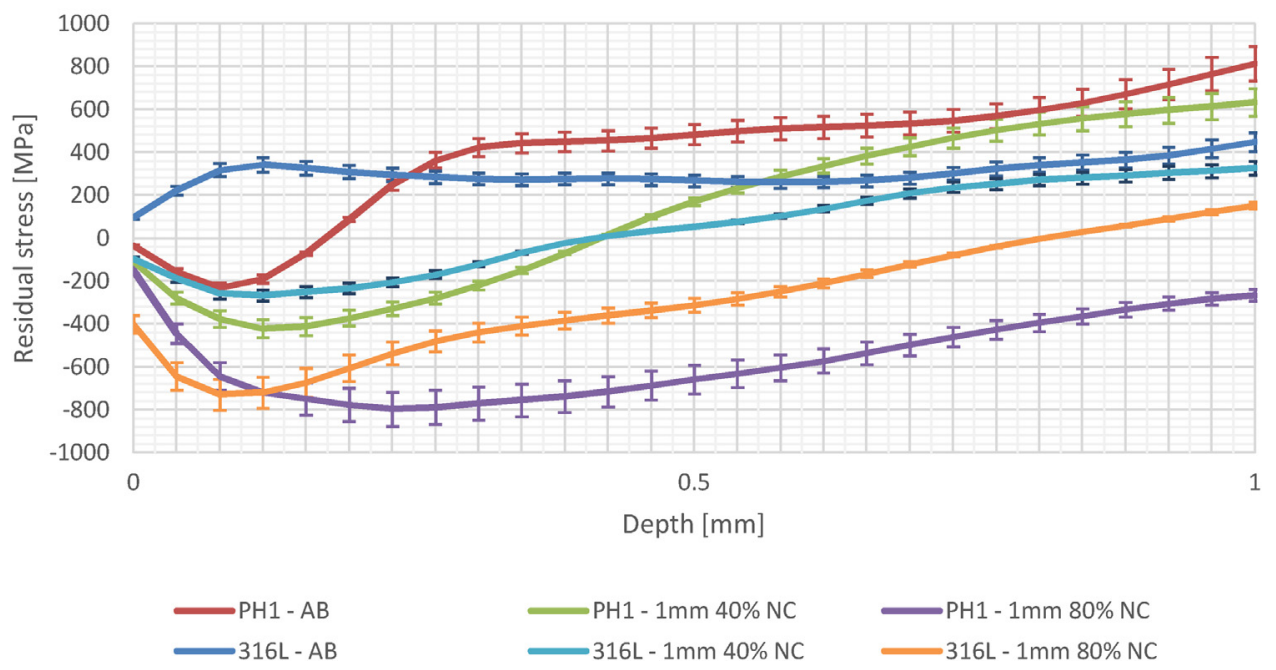

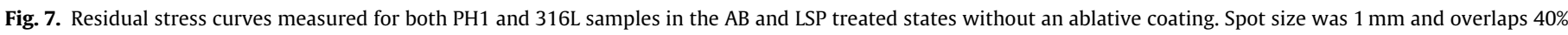
and $80 \%$.

\begin{abstract}
- When using an ablative coating the CRS increase is more pronounced for spot sizes of 2 and $5 \mathrm{~mm}$

- Higher overlap rates (80\%) lead to higher CRS and a deeper CRS profile. Although these LSP parameters give significantly better results, the associated higher number of impacts leads to longer processing time.
\end{abstract}

Further investigations will be done on the effect of the LSP treatment on the microstructure and the fatigue life of SLM parts. Also, the possibility of combining LSP treatment with SLM into a single machine will be addressed. The goal of using LSP during the building phase of SLM as a "3D LSP" method would be to tailor residual stresses throughout the part, especially focusing on critical points and in the near surface zone. This would possibly lead to increased depth and volume of CRS in the near surface region, which is known to have beneficial effects on fatigue life. Another goal would be to reduce the accumulation of TRS during the building phase, to avoid process failure for certain materials which are hard or even impossible to process by SLM (e.g. Ni-based superalloys).

\section{References}

[1] R.S. Gideon, N. Levy, Rapid manufacturing and rapid tooling with layer manufacturing (LM) technologies, state of the art and future perspectives, CIRP Ann. Manuf. Technol. 52 (2) (2017) 589-609.

[2] Wohlers Report 2012. [Online]. Available: http://www.wohlersassociates, com/2012report.htm. (Accessed: 11 September 2015).

[3] E. Yasa, K. Kempen, J.-P. Kruth, L. Thijs, J. Van Humbeeck, Microstructure and mechanical properties of maraging steel 300 after Selective Laser Melting, Presented at the Solid Freeform Fabrication Symposium Proceedings (2010).

[4] L. Thijs, J. Van Humbeeck, K. Kempen, E. Yasa, J.P. Kruth, M. Rombouts, Investigation on the inclusions in maraging steel produced by Selective Laser Melting, in: Innovative Developments in Virtual and Physical Prototyping, CRC Press, 2011, pp. 297-304.

[5] T. Niendorf, S. Leuders, A. Riemer, H.A. Richard, T. Tröster, D. Schwarze, Highly Anisotropic Steel Processed by Selective Laser Melting, Metall. Mater. Trans. B 44 (May (4)) (2013) 794-796.

[6] K. Kempen, L. Thijs, J. Van Humbeeck, J.-P. Kruth, Mechanical properties of AlSi10Mg produced by selective laser melting, Phys. Procedia 39 (2012) 439-446.

[7] H. Stoffregen, K. Butterweck, E. Abele, Fatigue analysis in selective laser melting: review and investigation of thin-walled actuator housings, in: Presented at the 25th Solid Freeform Fabrication Symposium 2014, Austin, Texas, 2014, pp. 635-650.

[8] D. Gu, et al., Densification behavior, microstructure evolution, and wear performance of selective laser melting processed commercially pure titanium, Acta Mater. 60 (9) (2012) 3849-3860.
[9] X. Tan, et al., Graded microstructure and mechanical properties of additive manufactured Ti-6Al-4 V via electron beam melting, Acta Mater. 97 (September) (2015) 1-16.

[10] T.H. Becker, M. Beck, C. Scheffer, Microstructure and mechanical properties of direct metal laser sintered TI-6AL-4V, South Afr. J. Ind. Eng. 26 (1) (2015) 1-10.

[11] L.T.B. Vrancken, Microstructure and mechanical properties of a novel $\beta$ titanium metallic composite by selective laser melting, Acta Mater. 68 (15) (2014) 150-158

[12] E. Sallica-Leva, A.L. Jardini, J.B. Fogagnolo, Microstructure and mechanical behavior of porous Ti?6Al? $4 \mathrm{~V}$ parts obtained by selective laser melting, J. Mech. Behav. Biomed. Mater. 26 (October) (2013) 98-108.

[13] H.K. Rafi, D. Pal, N. Patil, T.L. Starr, B.E. Stucker, Microstructure and mechanical behavior of 17-4 precipitation hardenable steel processed by selective laser melting, J. Mater. Eng. Perform. 23 (12) (2014) 4421-4428.

[14] J.-P. Kruth, M. Badrossamay, E. Yasa, J. Deckers, L. Thijs, J. VanHumbeeck, Part and material properties in selective laser melting of metals, Presented at the Proceedings of the 16th International Symposium on Electromachining (2010).

[15] J.-P. Kruth, J. Deckers, E. Yasa, R. Wauthle, Assessing and comparing influencing factors of residual stresses in selective laser melting using a novel analysis method, Proc. Inst. Mech. Eng. B J. Eng. Manuf. 226 (6) (2012) 980-991.

[16] C. Casavola, S.L. Campanelli, C. Pappalettere, Experimental analysis of residual stresses in the selective laser melting process, in: Proccedings of the XIth International Congress and Exposition, Orlando, Florida, USA, 2008.

[17] K. Kunze, T. Etter, J. Grässlin, V. Shklover, Texture, anisotropy in microstructure and mechanical properties of IN738LC alloy processed by selective laser melting (SLM), Mater. Sci. Eng. A 620 (January) (2015) 213-222.

[18] K. Kempen, B. Vrancken, S. Buls, L. Thijs, J. Van Humbeeck, J.-P. Kruth, Selective laser melting of crack-free high density M2 high speed steel parts by baseplate preheating, J. Manuf. Sci. Eng. 136 (October (6)) (2014) 061026.

[19] L. Thijs, et al., Strong morphological and crystallographic texture and resulting yield strength anisotropy in Selective Laser Melted tantalum, Acta Mater. 61 (12) (2013) 4657-4668.

[20] T.E.L. Rickenbacher, High temperature material properties of IN738LC processed by selective laser melting (SLM) technology, Rapid Prototyp. J. 19 (4) (2013)

[21] M. Simonelli, Y.Y. Tse, C. Tuck, Further Understanding of TAl4V Selective Laser Melting Using Texture Analysis, in: Proc. 23rd Annu. Int. Solid Free. Fabr. Symp., Austin TX, 2012.

[22] D. Buchbinder, W. Meiners, N. Pirch, K. Wissenbach, J. Schrage, Investigation on reducing distortion by preheating during manufacture of aluminum components using selective laser melting, J. Laser Appl. 26 (1) (2014) 012004.

[23] A.S. Wu, D.W. Brown, M. Kumar, G.F. Gallegos, W.E. King, An experimental investigation into additive manufacturing-Induced residual stresses in 316L stainless steel, Metall. Mater. Trans. A 45 (December (13)) (2014) 6260-6270.

[24] M. Shiomi, K. Osakada, K. Nakamura, T. Yamashita, F. Abe, Residual stress within metallic model made by selective laser melting process, CIRP Ann. Manuf. Technol. 53 (1) (2004) 195-198.

[25] P. Peyre, R. Fabbro, P. Merrien, H.P. Lieurade, Laser shock processing of aluminium alloys. Application to high cycle fatigue behaviour, Mater. Sci. Eng. A 2 (June) (1996) 102-113.

[26] U. Trdan, M. Skarba, J. Grum, Laser shock peening effect on the dislocation transitions and grain refinement of Al?Mg?Si alloy, Mater. Charact. 97 (November) (2014) 57-68. 
[27] T.W. Charles, S. Montross, Laser shock processing and its effects on microstructure and properties of metal alloys: a review, Int. J. Fatigue 24 (10) (2002) 1021-1036.

[28] R.K. Nalla, I. Altenberger, U. Noster, G.Y. Liu, B. Scholtes, R.O. Ritchie, On the influence of mechanical surface treatments-deep rolling and laser shock peening-on the fatigue behavior of Ti-6Al-V at ambient and elevated temperatures, Mater. Sci. Eng. A 355 (Aug. (1-2)) (2003) 216-230.

[29] I. Nikitin, B. Scholtes, H.J. Maier, I. Altenberger, High temperature fatigue behavior and residual stress stability of laser-shock peened and deep rolled austenitic steel AISI 304, Scr. Mater. 50 (10) (2004) 1345-1350.

[30] Y.K. Gao, Improvement of fatigue property in 7050-T7451 aluminum alloy by laser peening and shot peening, Mater. Sci. Eng. A (April (10-11)) (2011) 3823-3828.

[31] M. Dorman, M.B. Toparli, N. Smyth, A. Cini, M.E. Fitzpatrick, P.E. Irving, Effect of laser shock peening on residual stress and fatigue life of clad 2024 aluminium sheet containing scribe defects, Mater. Sci. Eng. A 548 (June) (2012) 142-151.

[32] J.J. Ruschau, R. John, S.R. Thompson, T. Nicholas, Fatigue crack nucleation and growth rate behavior of laser shock peened titanium, Int. J. Fatigue 21 (September) (1999) 199-209, Supplement 1.

[33] E. Maawad, H.-G. Brokmeier, L. Wagner, Y. Sano, C. Genzel, Investigation on the surface and near-surface characteristics of Ti-2. 5Cu after various mechanical surface treatments, Surf. Coat. Technol. 12 (205) (2011) 3644-3650.

[34] A.S. Gill, A. Telang, V.K. Vasudevan, Characteristics of surface layers formed on inconel 718 by laser shock peening with and without a protective coating, J. Mater. Process. Technol. 225 (2015) 463-472.

[35] D. Karthik, S. Swaroop, Laser shock peening enhanced corrosion properties in a nickel based Inconel 600 superalloy, J. Alloys Compd. 694 (2017) 1309-1319.

[36] Y. Li, et al., The strengthening mechanism of a nickel-based alloy after laser shock processing at high temperatures, Sci. Technol. Adv. Mater. 14 (October (5)) (2013) 055010

[37] M.A.S. Torres, H.J.C. Voorwald, An evaluation of shot peening, residual stress and stress relaxation on the fatigue life of AISI 4340 steel, Int. J. Fatigue 24 (August (8)) (2002) 877-886.

[38] A.H. Clauer, J.H. Holbrook, B.P. Fairand, Effects of laser induced shock waves on metals, in: M.A. Meyers, L.E. Murr (Eds.), Shock Waves and High-Strain-Rate Phenomena in Metals, Springer, US, 1981, pp. 675-702.

[39] A. King, A. Steuwer, C. Woodward, P.J. Withers, Effects of fatigue and fretting on residual stresses introduced by laser shock peening, Mater. Sci. Eng. A 436 (November) (2006) 12-18.

[40] O. Hatamleh, A comprehensive investigation on the effects of laser and shot peening on fatigue crack growth in friction stir welded AA 2195 joints, Int. J. Fatigue 31 (May (5)) (2009) 974-988.

[41] C.A. Rodopoulos, J.S. Romero, S.A. Curtis, E.R. de los Rios, P. Peyre, Effect of controlled shot peening and laser shock peening on the fatigue performance of 2024-T351 aluminum alloy, J. Mater. Eng. Perform. 12 (4) (2003) 414-419.
[42] A.K. Gujba, M. Medraj, Laser peening process and its impact on materials properties in comparison with shot peening and ultrasonic impact peening, Materials 7 (12) (2014) 7925-7974.

[43] EOS. Metal Materials for Additive Manufacturing. [Online]. Available: http:/ www.eos.info/material-m. (Accessed 12 October 2016).

[44] A.B. Spierings, T.L. Starr, K. Wegener, Fatigue performance of additive manufactured metallic partsnull, Rapid Prototyp. J. 19 (2) (2013) 88-94.

[45] D. Courapied, et al., Laser adhesion test for thermal sprayed coatings on textured surface by laser, J. Laser Appl. 28 (May (2)) (2016) 022509.

[46] D. Courapied, L. Berthe, P. Peyre, F. Coste, J.-P. Zou, A.-M. Sautivet, Laser-delayed double shock-wave generation in water-confinement regime, J. Laser Appl. 27 (February) (2015) S29101.

[47] C. Correa, et al., Random-type scanning patterns in laser shock peening without absorbing coating in 2024-T351 Al alloy: a solution to reduce residual stress anisotropy, Opt. Laser Technol. 73 (2015) 179-187.

[48] J.P. Nobre, M. Kornmeier, A.M. Dias, B. Scholtes, Use of the hole-drilling method for measuring residual stresses in highly stressed shot-peened surfaces, Exp. Mech. 40 (3) (2000) 289-297.

[49] C. Rubio-González, et al., Effect of laser shock processing on fatigue crack growth and fracture toughness of 6061-T6 aluminum alloy, Mater. Sci. Eng. A 386 (November (1)) (2004) 291-295.

[50] U. Trdan, J.A. Porro, J.L. Ocaña, J. Grum, Laser shock peening without absorbent coating (LSPwC) effect on 3D surface topography and mechanical properties of 6082-T651 Al alloy, Surf. Coat. Technol. 208 (2012) 109-116.

[51] N.S. Rossini, M. Dassisti, K.Y. Benyounis, A.G. Olabi, Methods of measuring residual stresses in components, Mater. Des. 35 (2012) 572-588.

[52] G.S. Schajer, Relaxation methods for measuring residual stresses: techniques and opportunities, Exp. Mech. 50 (8) (2010) 1117-1127.

[53] V.M. Measurements, Measurement of residual stresses by the hole drilling strain gage method, Tech Note TN-503-6, 2007.

[54] R.H. Leggatt, Residual stresses in welded structures, Int. J. Press. Vessels Pip. 85 (3) (2008) 144-151.

[55] D. Thibault, P. Bocher, M. Thomas, Residual stress and microstructure in welds of $13 \% \mathrm{Cr}-4 \% \mathrm{Ni}$ martensitic stainless steel, J. Mater. Process. Technol. 4 (February) (2009) 2195-2202.

[56] A. Griffiths, W. Nimmo, B. Roebuck, G. Hinds, A. Turnbull, A novel approach to characterising the mechanical properties of supermartensitic $13 \mathrm{Cr}$ stainless steel welds, Mater. Sci. Eng. A 2 (October) (2004) 83-91.

[57] P. Peyre, R. Fabbro, L. Berthe, X. Scherpereel, A. Le Cornec, Laser shock processing with small impacts, Proc. SPIE 2789 (1996) 125-132.

[58] P. Peyre, L. Berthe, X. Scherpereel, R. Fabbro, Laser-shock processing of aluminium-coated 55C1 steel in water-confinement regime, characterization and application to high-cycle fatigue behaviour, J. Mater. Sci. 33 (6) (1998) 1421-1429. 